\title{
Essential Oil Composition of Some Sage (Salvia spp.) Species Cultivated in İzmir (Turkey) Ecological Conditions
}

\author{
Ünal Karik ${ }^{1}$ Orçun Çinar², Murat Tunçtürk ${ }^{3}$, Nazım Şekeroğlư ${ }^{4}$, Sevgi Gezici ${ }^{5}$ \\ ${ }^{1}$ Aegean Agricultural Research Institute-İzmir, TURKEY. \\ ${ }^{2}$ West Mediterranean Agricultural research Institute-Antalya, TURKEY. \\ ${ }^{3}$ Yuzuncu YIl University, Agricultural Faculty, Field Crops Department, Van, TURKEY. \\ ${ }^{4}$ Kilis 7 Aralık University, Engineering and Architecture Faculty, Department of Food Engineering, Kilis, TURKEY. \\ ${ }^{5}$ Kilis 7 Aralık University, Science and Art Faculty, Department of Molecular Biology and Genetics, Kilis, TURKEY.
}

\begin{abstract}
Background: Salvia L., the largest genus of Lamiaceae, includes about 1000 species, widespread throughout the world. This genus is represented, in Turkish flora, by 99 species and 113 taxa, 58 of which are endemic. Some members of this genus are of economic importance since they have been used as herbal tea, flavouring agents in perfumery and cosmetics. Some sage (Salvia L. ) species has been credited with a long list of medicinal uses: e.g. spasmolytic, antiseptic, astringent. Objective: In present study, essential oil composition of some sage (Salvia L.) species cultivated in Izmir (Turkey) was investigated. Sage species have recently become more common in Turkey and sage cultivation is increasing especially in the Aegean Region. Material and Methods: The species of Salvia fruticosa Mill., Salvia officinalis L., Salvia sclarea L., hybrid (Salvia fruticosa Mill. x Salvia officinalis L.) and Salvia dichroantha L. were used in the study. Essential oils were extracted according to hydro distillation method with clevenger type apparatus and analyzed using GC-FID and GC-MS system. Results: Essential oil contents of Salvia fruticosa Mill. was 3.86\%, Salvia officinalis L. 2.42\%, Salvia sclarea L. $0.5 \%$, Salvia fruticosa Mill. x Salvia officinalis L. $2.84 \%$ and Salvia dichroantha L. $0.19 \%$. The number of components in essential oils were detected 22, 16, 14, 20 and 16 respectively. The chemical composition of the essential oils in Salvia fruticosa Mill. 1,8-cineole (57.18\%), Salvia officinalis L. $\beta$-thujone (34.59\%), Salvia sclarea L. linalyl acetate $(46.77 \%)$, Salvia fruticosa Mill. x Salvia officinalis L. 1,8-cineole $(21.42 \%)$ and $\beta$-thujone $(18.37 \%)$ and Salvia dichroantha L. $\beta$ - caryophyllene $(23.11 \%)$ and sabinyl acetate $(21.87 \%)$.
\end{abstract}

Key words: Salvia spp., Sage, Cultivation, Essential oil, Chemcial composition.

\section{INTRODUCTION}

Plant species have been utilized as a source of food, fragrance and medicine for millennia throughout the world. The family Lamiaceae has been extensively known to have immense medicinal, pharmacological and industrial properties. Many of these species within the Lamiaceae family has a potential of possessing essential oils which can be supplied to industry as raw material for different application in preparation of insecticides, antiseptics, perfumes, spices and many other commodities. ${ }^{1}$
The genus Salvia L. is the largest genus in the Lamiaceae, comprising nearly 1000 species. Salvia L. has radiated extensively in three regions of the world, Central and South America (500 spp.), West (200 spp.) and East Asia (100spp.). ${ }^{2}$ This genus is represented, in Turkish flora, by 99 species and 14 subspecies totally 113 taxa, 58 of which are endemic. ${ }^{3}$ Some members of this genus are of economic importance since they have been used as herbal tea, flavouring agents in
Submission Date: 30-08-2016; Revision Date: 17-11-2016; Accepted Date: 23-11-2016

DOI: 10.5530/ijper.52.4s.83 Correspondence: Ünal Karik,

Aegean Agricultural Research Institute-İzmir, TURKEY.

Phone: +90 2328461331 451

E-mail: unalkarik@gmail.com unal.karik@tarim.gov.tr

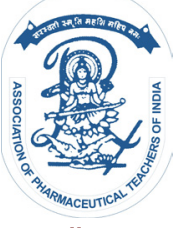

www.ijper.org 
perfumery and cosmetics. Some sage (Salvia L. ) species has been credited with a long list of medicinal uses: e.g. spasmolytic, antiseptic, astringent. Since ancient times, species of Salvia L. have been used in folk medicine for the treatment of diabetes and skin diseases such as psoriasis and eczema. Numerous species of the genus Salvia L. have been used since ancient times in folk medicine and subjected to extensive pharmacognosic research intended to identify biologically active compounds. Salvia L. species contain various secondary metabolites such as sterols, flavonoids, sesquiterpenoids, sesterpenoids, diterpenoids, triterpenoids, essential oils, and flavonoids. ${ }^{4}$ The analysis of the essential oil composition of several Salvia L. species indicates that 1,8-cineole (eucalyptol), $\alpha$ and $\beta$-thujone, $\alpha$ and $\beta$-pinene and borneol are its main constituents. However, several authors have documented significant species specific variations in the concentration of these compounds and/or presence of others in high concentrations. ${ }^{2}$ Moreover, the essential oil composition of Salvia L. species, as occurs with other medicinal and aromatic plants, is highly influenced by genetic and environmental factors. ${ }^{4}$ Salvia L. taxa of Turkey were classifed by according to main components in their respective essential oils as 1,8-cineole/camphor group: Salvia fruticosa Mill., thujone group: Salvia officinalis L., linalyl acetate/linalool group: Salvia sclarea L. and $\beta$-caryophyllene group: Salvia dichroantha L.$^{5}$

\section{Experimental}

\section{Plant material}

Plants were harvested during the flowering period from field experiment area of Aegean Agricultural Research Institute. Plant samples which included leaves and flowers were collected to the two years old plants.

\section{Isolation of the Essential Oils}

The essential oils from air-dried plant materrials were isolated by hydrodistillation for $3 \mathrm{~h}$, using a clevenger-type apparatus. ${ }^{6}$ The obtained oils were dried over anhydrous sodium sulphate and stored at $+4^{\circ} \mathrm{C}$ in the dark until analysed and tested.

\section{GC-MS analysis}

The essential oil composition of samples was analyzed by gas chromatography (Agilent 5975C) coupled to flame ionization detector and mass spectrometry (Agilent 5975C) using capillary column (HP Innowax Capillary; $60.0 \mathrm{~m} \times 0.25 \mathrm{~mm} \times 0.25 \mu \mathrm{m})$. Essential oils were diluted 1:50 ratio with hexane. GC-MS/FID analysis was carried out at split mode of 50:1. Injection volume and temperature were adjusted as $1 \mu \mathrm{l}$ and $250^{\circ} \mathrm{C}$, respectively. Helium $(99.9 \%$ ) was the carrier gas at a constant flow rate of $1 \mathrm{ml} / \mathrm{min}$. The oven temperature was programmed as follows: $60^{\circ} \mathrm{C}$ for $10 \mathrm{~min}$, increased at $20^{\circ} \mathrm{C} / \mathrm{min}$ to $250^{\circ} \mathrm{C}$, and held at $250^{\circ} \mathrm{C}$ for $8 \mathrm{~min}$. MS spectra were monitored between 35 and $450 \mathrm{amu}$ and the ionization mode used was electronic impact at $70 \mathrm{eV}$.

\section{Identification of Compounds}

The relative percentage of the components was calculated from GC-FID peak areas, and components were identified by Wiley $7 \mathrm{n}$, Nist 05 and Flavour and Fragrance Natural and Synthetic Compounds (ver. 1.3) Libraries.

\section{RESULTS AND DISCUSSION}

The essential oil yield of five Salvia L. species were studied in this study is summarized in Table 1. The essential oil yield of Salvia fruticosa Mill., Salvia officinalis L., Salvia sclarea L., hybrid (Salvia fruticosa Mill. x Salvia officinalis L.) and Salvia dichroantha L. were obtained $3.86 \%, 2.42 \%, 0.5 \%, 2.84 \%$ and $0.19 \%$ respectively. In our study the highest yield of essential oil was obtained in Salvia fruticosa Mill. (3.86\%) and the lowest in Salvia dichroantha L. $(0.19 \%)$. The essential oil yield of Salvia fruticosa Mill. were found between 1.14\%-4.58\% in different studies in the Flora of Turkey. ${ }^{7-10}$ Salvia fruticosa Mill. essential oil yield has been previously studied in different countries. Salvia fruticosa Mill. essential oil yield were obtained; in 1986, Putievsky et al. ${ }^{11} 1.4 \%-3.8 \%$ in Israel, in 1993, Cao et al. ${ }^{12} 2-3 \%$, in Italy, in 1997, Karousou and Kokkini ${ }^{13}$ 1\%-5.5\% in Crete and in 2011, Mossi et al..$^{14} 0.98 \%$ in Brasil. In our study we found Salvia officinalis $\mathrm{L}$. essential oil yield was $2.42 \%$. The essential oil of common sage (Salvia officinalis L.) has been previously studied. They reported; in 1987, Ceylan et al. ${ }^{15} 0.85 \%-2.13 \%$, in 1991, Bernath et al. ${ }^{16} 1.5 \%-2.5 \%$, Salvia officinalis L. essential oil in different studies. When we focused on Salvia sclarea L., we found 0.5\% essential oil while in 1986, Şarer, ${ }^{17}$ in 2005, Fraternale et al. ${ }^{18}$ and in 2012, Sharopov et al. ${ }^{19}$ reported that Salvia sclarea L. was included $0.25 \%, 0.15 \%$ and $0.30 \%$ essential oil. Hybrid sage (Salvia fruticosa Mill. $\times$ Salvia officinalis L.) was improved in our Institute and it contains $2.84 \%$ essential oil. The last species is Salvia dichroantha $\mathrm{L}$. and we obtained $0.19 \%$ of essential oil. In 1986, Şarer ${ }^{17}$ and in 2002, Başer ${ }^{5}$ reported that Salvia dichroantha $\mathrm{L}$. included $0.2 \%$ and $0.15 \%$ essential oil. It is known that genetic constitution and environmental conditions influence the yield and composition of volatile oil produced by medicinal plants. ${ }^{20}$

We identified 22, 16, 14, 20 and 16 components in essential oils belong to Salvia fruticosa Mill., Salvia officinalis L., Salvia sclarea L., hybrid (Salvia fruticosa Mill. $\times$ Salvia 


\section{Table 1: The composition of the essential oil of Cutivated Sage Species (Salvia spp.).}

\begin{tabular}{|c|c|c|c|c|c|c|}
\hline \multirow{2}{*}{ RRI } & \multirow{2}{*}{ Components } & \multicolumn{5}{|c|}{ Species } \\
\hline & & $\mathbf{S F}^{*}$ & so* & SS* $^{*}$ & SFxO* & SD* \\
\hline 1002 & $\alpha$-pınene & 3,40 & 3,38 & - & 6,46 & 0,73 \\
\hline 1006 & a-thujene & 0,52 & - & - & - & - \\
\hline 1046 & camphene & 0,44 & 4,22 & - & 2,88 & - \\
\hline 1090 & $\beta$-pınene & 8,20 & 4,10 & - & 8,70 & - \\
\hline 1104 & sabınene & 0,43 & - & - & - & - \\
\hline 1144 & myrcene & 5,66 & 0,99 & 0,85 & 1,93 & - \\
\hline 1162 & a-terpınene & 0,55 & - & - & 0,59 & - \\
\hline 1182 & lımonene & 1,12 & 1,09 & - & 1,14 & - \\
\hline 1192 & 1,8-cıneole & 57,18 & 4,02 & - & 21,42 & - \\
\hline 1227 & gamma-terpınene & 1,33 & 0,59 & - & 1,36 & - \\
\hline 1232 & $\beta$-ocımene & - & - & - & 0,65 & - \\
\hline 1253 & cymene & 0,40 & - & - & 0,89 & - \\
\hline 1264 & a-terpınolene & 0,29 & - & - & - & - \\
\hline 1408 & $\beta$-thujone & 3,07 & 34,59 & - & 18,37 & - \\
\hline 1428 & a-thujone & 1,48 & 12,60 & - & 4,11 & - \\
\hline 1442 & cIs-sabınene hydrate & 0,61 & - & - & - & - \\
\hline 1476 & a-copaene & - & - & 0,66 & - & - \\
\hline 1502 & $\beta$-bourbonene & - & - & - & - & 0,62 \\
\hline 1505 & camphor & 3,15 & 10,09 & - & 6,02 & - \\
\hline 1517 & Iınalool & - & - & 11,74 & - & - \\
\hline 1532 & Iınalyl acetate & - & - & 46,77 & - & - \\
\hline 1563 & bornyl acetate & - & 1,08 & - & - & - \\
\hline 1584 & $\beta$-caryophyllene & 4,83 & 3,45 & 1,53 & 11,26 & 23,11 \\
\hline 1593 & aromadendrene & 0,95 & - & - & - & \\
\hline 1629 & sabınyl acetate & - & - & - & - & 21,87 \\
\hline 1656 & a-humulene & 2,85 & 5,72 & - & 2,34 & 1,82 \\
\hline 1670 & gamma-cadınene & - & - & - & - & 0,85 \\
\hline 1673 & a-terpıneol & - & - & 4,39 & 0,48 & - \\
\hline 1679 & borneol & 0,35 & 4,45 & - & 3,40 & - \\
\hline 1696 & germacrene & - & - & 16,27 & - & 7,29 \\
\hline 1706 & $\beta$-selınene & - & - & - & - & 0,64 \\
\hline 1720 & neryl acetate & - & - & 4,12 & - & - \\
\hline 1721 & bıcyclogermacrene & - & - & - & - & 2,59 \\
\hline 1737 & delta-cadınene & - & - & - & - & 1,13 \\
\hline 1768 & nerol & - & - & 1,10 & - & - \\
\hline 1812 & geranıol & - & - & 3,15 & - & - \\
\hline 1980 & caryophyllene oxıde & - & - & - & 0,55 & 10,98 \\
\hline 2063 & guaıol & - & - & - & - & 4,46 \\
\hline 2066 & virıdıflorol & 2,89 & 6,24 & - & 6,61 & - \\
\hline 2104 & spathulenol & 0,33 & - & - & - & 11,55 \\
\hline 2130 & farnesol & - & - & 0,86 & - & - \\
\hline 2146 & epıbıcyclosesquiphellandrene & - & - & 1,18 & - & - \\
\hline 2185 & bulnesol & - & - & - & - & - \\
\hline 2199 & 8-cedren-13-ol & - & - & - & - & - \\
\hline 2273 & caryophylla-4,8-dien-5-beta-ol & - & - & - & - & - \\
\hline 2212 & $\beta$-eudesmol & - & - & 1,11 & - & 0,72 \\
\hline 2244 & sclareoloxıde & - & - & 1,49 & - & 0,59 \\
\hline 2636 & 13-epı manool & - & 2,67 & - & 0,84 & 0,91 \\
\hline & Total $(\%)$ & 100 & 100 & 95,22 & 100 & 89,85 \\
\hline & Essential Oil (\%) & 3,86 & 2,42 & 0,50 & 2,84 & 0,19 \\
\hline
\end{tabular}

SF* = Salvia fruticosa Mill., SO*= Salvia officinalis L., SS*= Salvia sclarea $\mathrm{L}$.

$\mathrm{SFxO} *=$ Salvia fruticosa Mill. $\times$ Salvia officinalis $\mathrm{L} ., \mathrm{SD}^{*}=$ Salvia dichroantha $\mathrm{L}$. 
officinalis L.) and Salvia dichroantha L.. These componets are representing $100 \%, 100 \%, 95.22 \% 100 \%$ and $89.85 \%$ of the total composition of essential oils respectively.

The chemical composition of Salvia fruticosa Mill. essential oil is summarized in Table 1. A total of 22 compounds were identified representing 100\% of the total composition. The oil was dominated by the 1,8-cineole $(57.18 \%)$ and the other major component was $\beta$-pinene $(8.20 \%)$.

In 2002, Başer ${ }^{15}$ studied on Turkish Salvia L. species and reported that Salvia fruticosa Mill. belong to 1,8-cineole and camphor group and their amount changed 35\%-51\% and 7\%-13\%. Salvia fruticosa Mill. essential oils were studied in different countries and they found the major component as 1,8-cineole and reported that its percentage between $15.28 \%$ and $80.80 \%{ }^{16-17}$

Composition of the essential oil obtained from Salvia officinalis L. is included three major components as $\beta$-thujone $34.59 \%, \alpha$-thujone $12.6 \%$ and camphor $10.09 \%$. Chemical composition of the Salvia officinalis L. essential oil have been reported for several studies. Main components and their amonut of Salvia officinalis L. essential oil which mentioned studies were described as; in 2007, Ekren et al. ${ }^{21} \alpha$-thujone $12.62 \%-39.29 \%$ and camphor 5.06\%-30.97\%, in 2000, Miladinovic and Miladinovic ${ }^{22} \alpha$-thujone $24.88 \%$ and camphor $16.03 \%$, in 2000, Salameh and Dordevic ${ }^{23} \alpha$-thujone 29.9\%, $\beta$-thujone $13.68 \%$ and camphor $15.74 \%$, in 2000 , Sagareishvili et al. ${ }^{24} \alpha$-thujone $31.56 \%$, $\beta$-thujone $17.55 \%$ and camphor $16.48 \%$.

The chemical composition of Salvia sclarea L. essential oil is included of 14 compounds were identified representing $95.22 \%$ of the total composition. The oil was dominated by the linalyl acetate $(46.77 \%)$, germacrene $(16.27 \%)$ and linalool (11.74\%). Previous studies have also yielded similar results. ${ }^{17-19}$ Hybrid sage (Salvia fruticosa Mill. x Salvia officinalis L.) essential oil was included 20 compounds and the main constituens were 1,8-cineole (21.42\%) and $\beta$-thujone (18.37). The compounds identified from the Salvia dichroantha L. essential oil along with its relative percentages are listed in Table 1. A total of 16 compounds were identified from the essential oil which represented $89.85 \%$ of the oil. The main components of Salvia dichroantha L. essential oil were found as $\beta$-caryophyllene (23.11\%) and sabinyl acetate $(21.87 \%)$. In 1986, Şarer ${ }^{17}$ and in 2002, Başer ${ }^{5}$ reported $\beta$-caryophyllene and sabinyl acetate as the main compounds of Salvia dichroantha L. from Turkey.

\section{CONCLUSION}

The yield and chemical composition of the essential oils were determined in Salvia fruticosa Mill. 3.86\% 1,8-cineole (57.18\%), Salvia officinalis L. 2.42\% $\beta$-thujone $(34.59 \%)$, Salvia sclarea L. $0.50 \%$ linalyl acetate $(46.77 \%)$, Salvia fruticosa Mill. x Salvia officinalis L. $2.84 \%$ 1,8-cineole $(21.42 \%)$ and $\beta$-thujone $(18.37 \%)$ and Salvia dichroantha L. $0.19 \% \beta$ - caryophyllene $(23.11 \%)$ and sabinyl acetate $(21.87 \%)$.

\section{ACKNOWLEDGEMENT}

The authors are thankful for the technical helping to the Aegean Agricultural Research Institute and West Mediterranean Agricultural Research Institute.

\section{CONFLICT OF INTEREST}

The authors declare no conflict of interest.

\section{ABBREVIATIONS}

GC: Gas chromatography; GC-MS: Gas chromatography-mass spectrometry; FID: Flame Ionization Detector; GC-FID: Gas chromatography with Flame Ionization Detector; RRI: Relative retention indices.

\section{REFERENCES}

1. Buyisile EB, Magwa LM, Coopoosamy RM. The chemical composition and antibacterial activity of the leaf extract of Salvia repens Burch. Journal of Medicinal Plants Research. 2008;2(7):159-62.

2. Atsuko $\mathrm{T}$, Hiroshi $\mathrm{O}$. Phylogenetic relationships among subgenera, species, and varieties of Japanese Salvia L. (Lamiaceae). J. Plant Res. 2011;124(2):245-52.

3. Güner A. Türkiye bitkileri listesi. 2012.

4. Lu Y, Foo LY. Polyphenolics of Salvia - a review. Phytochemistry. 2002;59(2):117-40.

5. Başer $\mathrm{KH}$. Aromatic biodiversity among the flowering plant taxa of Turkey. Pure Applying Chemistry. 2002;74(4):527-45.

6. Gezici S, Sekeroglu N, Kijjoa A. in vitro Anticancer Activity and Antioxidant Properties of EOs from Populus alba and Rosmarinus officinalis Growing in South Eastern Anatolia of Turkey. Indian Journal of Pharmaceutical Education and Research (IJPER). 2017;51(3):S498-S503.

7. Aşkun T, Başer KHC, Tümen G, Kürkçüoğlu M. Characterization of essential oils of some Salvia L. species and their antimycobacterial activities. Turkish Journal of Biology. 2010;34:89-95.

8. Kocabaş FI, Kaplan M, Kürkçüoğlu M, Başer KHC. Effects of different organic manure applications on the essential oil components of Turkish sage (Salvia fruticosa Mill.). Asian Journal of Chemistry. 2010;22(2):1599-605.

9. Çiçek F, Tutar M, Sarı AO, Bilgiç A. Anadolu adaçayı (Salvia fruticosa Mill.) yapraklarında uçucu yağ oranlarının aylara göre değişimi. Türkiye 9. Tarla Bitkileri Kongresi. Endüstri Bitkileri ve Biyoteknoloji. 2011;2:1287-90.

10. Karık Ü. Some Morpholocigal, Yield and Quality Characteristics of Anatolian Sage (Salvia fruticosa Mill.) Populations in Aegean and West Mediterranean Region. Journal of Tekirdag Agricultural Faculty. 2015;12(2):32-42.

11. Putievsky E, Ravid U, Dudai N. The essential oil and yield components from various plant parts of Salvia fruticosa Mill. Journal of Natural Products. 1986;49(6):1015-7. 
12. Cao G, Alessio HM, Cutler RG. Oxygen-radical absorbance capacity assay for antioxidants. Free Radical Biology and Medicine. 1993;14(3):303-11.

13. Karoussou R, Kokkini S. Distrubition and clinal varitian of Salvia fruticosa Mill. (Labiateae) on the Island of Crete ( Greece). Willdenowia. 1997;27(1/2):113-7.

14. Mossi AJ, Cansian RL, Paroul N, Toniazzo G, Oliveira JV, Pierozan MK, et al. Morphological characterisation and agronomical parameters of different species of Salvia L. sp. (Lamiaceae). Brazilian Journal of Biology. 2011;71(1):121-9.

15. Ceylan A. Tıbbi Bitkiler II (Uçucu Yağ İçerenler). Ege Üniversitesi Yayınları Yayın No: 48. 1987;188s. İzmir.

16. Bernàth J, Danos B, Hethelyi E. Variation of Essential Oil Spectrum of Salvia L. species Affected by Environment. Herba Hungarica. 1991;30(1-2):35-48.

17. Şarer E. Güney ve İç Anadolu Bölgelerinde Yetişen Salvia Adaçayı yağlarının İlaç ve Parfümeri Hammaddesi Yönünden İncelenmesi. Tübitak Proje No: TAG-517. 1986; 64 p.

18. Fraternale D, Giamperi L, Bucchini A, Ricchi D, Epifano F, Genovese S, et al. Composition and antifungal activity of essential oil of Salvia sclarea L. from Italy. Chem. Nat. Comp. 2005;41(5):604-6.
19. Sharopov FS, Setzer WN. The Essential Oil of Salvia sclarea L. from Tajikistan. Rec. Nat. Prod. 2012;6(1):75-9.

20. Ramezani S, Ramezani F, Rasouli F, Ghasemi M, Fotokian MH. Diurnal Variation of the Essential Oil of Four Medicinal Plants Species in Central Region of Iran. Research Journal of Biological Sciences. 2009;4(1):103-6.

21. Ekren S, Sönmez Ç, Sancaktaroğlu S, Bayram E. Farklı Biçim Yüksekliklerinin Adaçayı (Salvia officinalis L.) Genotiplerinde Agronomik ve Teknolojik Özelliklere Etkisinin Belirlenmesi. Ege Üniv. Ziraat Fak. Derg. 2007;44(1):55-70.

22. Miladinovic D, Miladinovic LJ. Animicrobial Activity of Essential oil of Sage from Serbia. Physics, Chemistry and Technology. 2000;2(2):97-100.

23. Amr S, Dordevic S. The Investigation of the Quality of Sage (Salvia officinalis L.) from Jordan. University of Niš. The Scientific Journal Facta Unversitatis, Series: Working and Living Environmental Protection. 2000;1(5):103-8.

24. Sagareishvili TG, Grigolava BL, Gelashvili NE, Kemertelidze EP. Composition of Essential Oil from Salvia officinalis L. Cultivated in Georgia. Chemistry of Natural Compounds. 2000;36(4):360-1.

\section{PICTORIAL ABSTRACT}

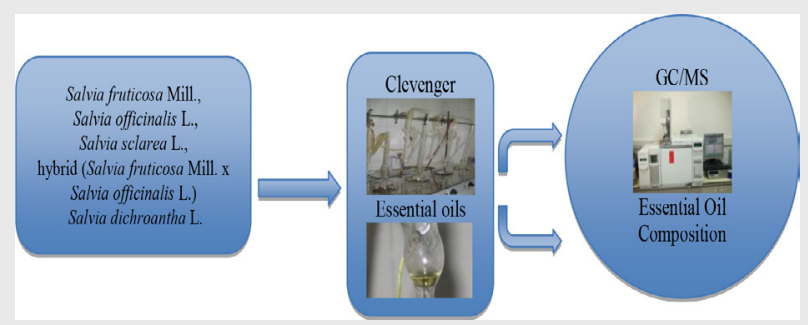

\section{About Authors}

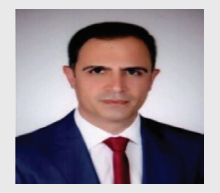

Dr. Ünal KARIK: He is working as a researcher in Aegean Agricultural Research Institute Izmir/TURKEY. Research interests include medicinal and aromatic especially essential oil plants. He contunies domestication, breeding and improve new cultivars on these plants.

\section{SUMMARY}

- The genus Salvia L. is the largest genus in the Lamiaceae, comprising nearly 1000 species. Salvia L. has radiated extensively in three regions of the world, Central and South America (500 spp.), West (200 spp.) and East Asia (100spp.). This genus is represented, in Turkish flora, by 99 species and 14 subspecies totally 113 taxa, 58 of which are endemic.

- Our objectives are to find out the composition of the essential oil from aerial parts of Salvia L. species cultivated in Turkey, using GC-FID and GC-MS.

- Salvia fruticosa Mill. 1,8-cineole (57.18\%), Salvia officinalis L. $\beta$-thujone (34.59\%), Salvia sclarea L. linalyl acetate $(46.77 \%)$, Salvia fruticosa Mill. x Salvia officinalis L. 1,8-cineole (21.42\%) and $\beta$-thujone $(18.37 \%)$ and Salvia dichroantha L. $\beta$-caryophyllene $(23.11 \%)$ and sabinyl acetate $(21.87 \%)$ were found main components in the essential oils.

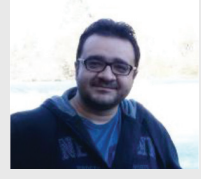

Orçun ÇINAR: He is working as a researcher in West Mediterranean Agricultural Research InstituteAntayla/TURKEY. He is a chemical engineer and focused analyse of medicinal and aromatic plants with GC/MS, HPLC and LC/MS-MS.

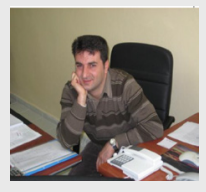

Prof. Dr. Murat TUNÇTÜRK: He earned his BsC in Agricultural Engineering, Prof. Dr. Tunçtürk earned his PhD degree on Industrial Plants Yuzuncu Yil University, Turkey. He is interested in aromatic and Industrial plants since his undergraduate education. He is currently a full-time professor at Yuzuncu Yil University, Agricultural Faculty, Department of Field Crops. He published over 110 peer-reviewed articles and still active on his research area. Additionally, he is a member of scientific commissions about Medicinal and Aromatic Plants at Food and Agriculture in Turkey. He has visited more than 20 different countries for scientific purposes.

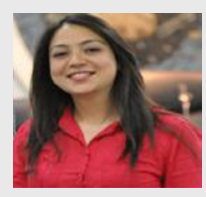

Assist. Prof. Dr. Sevgi Gezici: After completing her Ms in Molecular Biology and Genetic at Department of Biology, Gaziantep University, Turkey, she earned her Ph.D degree in the Molecular Biology and Genetics form the same University. She has received scholarships for her MSc and Ph.D from TUBITAK, which is the best research center in Turkey. She is currently assistant professor at Kilis 7 Aralik University, Department of Molecular Biology and Genetics. 
Prof. Dr. Nazim Sekeroglu: He earned his BsC in Agricultural Engineering, Prof. Dr. Sekeroglu earned his $\mathrm{PhD}$ degree on Medicinal and Aromatic Plants Cukurova University, Turkey. He is interested in medicinal and aromatic plants since his undergraduate education. He is currently a full-time professor at Kilis 7 Aralik University, Department of Medicinal and Aromatic Plants. He published over 100 peer-reviewed articles and still active on his research area. Additionally, he has organized many international scientific meetings, including congress, symposiums and workshops as chairperson. Furthermore, he is the founder of the Association of medicinal and Aromatic Plants of Mediterranean (AMAPMED), also he is general coordinator of Global Federation of Medicinal and Aromatic Plants (GOFMAP), a worldwide non-profit organization gathering associations related 'Medicinal and Aromatic Plants'. Moreover, he is a member of scientific commissions about Medicinal and Aromatic Plants at Food, Agriculture, Forestry and Health Ministries in Turkey. He has visited more than 50 different countries for scientific purposes.

Cite this article: Karik Ü, Çinar O, Tunçtürk M, Sekeroglu N, Gezici S. Essential Oil Composition of Some Sage (Salvia spp.) Species Cultivated in İzmir (Turkey) Ecological Conditions. Indian J of Pharmaceutical Education and Research. 2018;52(4S):S102-S107. 